\title{
Hubungan Minat Belajar Siswa Terhadap Kemampuan Komunikasi dan Kemandirian Siswa pada Materi Teorema Pythagoras
}

\author{
Siti Liwinda Rumapea ${ }^{1}$, Laili Habibah Pasaribu ${ }^{2}$ \\ 1,2 Program Studi Pendidikan Matematika, Fakultas Ilmu Pendidikan, Universitas Labuhanbatu, \\ J1. Sisingamangaraja Labuhanbatu Sumatera Utara (21415) Indonesia \\ sitiliwinda@gmail.com
}

\begin{abstract}
The purpose and problem formulation of this study is to determine whether the independence of students in the Pythagorean theorem can affect students' interest in learning towards communication skills. This research method is correlation's research. This research was conducted at SMP Negeri 1 Pangkatan in February - March 2021 in the even semester of the 2020/2021 academic year. The sample in this study was 30 students who were taken from the total population of data and could represent the entire population with a sample collection technique, namely the random sampling technique. The instruments used were tests and questionnaires with data analysis techniques using multiple regression tests. Based on the results of this study, it produces a significant value of $0.377<0.05$ and $\mathrm{F}$ counts $1.005<\mathrm{F}$ table 3.34 . With the effect of student interest in learning on communication skills simultaneously to the variabel, $\mathrm{Y}$ is $59 \%$. Tt can be concluded that there is an effect of student interest in student communication skills and independence on the subjcet of the Pythagorean theorem.
\end{abstract}

Keywords: Interest in Learning, Communication Skills, Student Independence

\begin{abstract}
Abstrak
Tujuan dan rumusan masalah dari penelitian ini adalah untuk mengetahui apakah dengan kemandirian siswa pada materi teorema pythagoras dapat mempengaruhi minat belajar siswa terhadap kemampuan komunikasi. Metode penelitian ini adalah penelitian korelasional. Penelitian ini dilakukan di SMP Negeri 1 Pangkatan pada bulan FebruariMaret Tahun 2021 pada semester genap Tahun Pembelajaran 2020/ 2021. Sampel dalam penelitian ini sebanyak 30 siswa yang di ambil dari jumlah populasi data dan dapat mewakili seluruh populasi dengan teknik pengumpulan sampel yaitu teknik random sampling. Instrumen yang digunakan adalah tes dan angket dengan teknik analisis data yang dilakukan yaitu dengan menggunakan uji regresi berganda. Dengan pengaruh minat belajar siswa terhadap kemampuan komunikasi secara simultan (bersamaan) terhadap variabel Y adalah sebesar 59\%. Sehingga dapat disimpulkan bahwa terdapat pengaruh minat belajar siswa terhadap kemampuan komunikasi dan kemandirian siswa pada materi teorema pythagoras.
\end{abstract}

Kata kunci: Minat Belajar, Kemampuan Komunikasi, Kemandirian Siswa

Copyright (c) 2021 Siti Liwinda Rumapea, Laili Habibah Pasaribu

$\checkmark$ Corresponding author: Siti Liwinda Rumapea

Email Address: sitiliwinda@gmail.com (Jl. Sisingamangaraja Labuhanbatu Sumatera Utara (21415) Indonesia)

Received 21 June 2021, Accepted 26 June 2021, Published 11 Juli 2021

\section{PENDAHULUAN}

Matematika adalah mata pelajaran yang ditemui disekolah bahkan dikehidupan sehari-hari. Menurut (Mayasari \& Rosyana, 2019) Ilmu matematika sering dilakukan untuk kegiatan dikehidupan sehari-hari, jadi matematika sangat berguna untuk dipelajari oleh seluruh siswa-siswi. Pendapat (Ernawati, 2020) Belajar matematika yaitu kegiatan yang dilakukan untuk mendapatkan suatu bidang ilmu baik secara langsung ataupun tidak langsung melalui lingkungan yang bisa memberikan perubahan sifat pada seseorang. Tujuan pembelajaran matematika di setiap jenjang pendidikan yang sudah disusun pada kurikulum. Oleh sebab itu siswa ditekankan untuk menguasai matematika, supaya siswa bisa memahami matematika secara menyeluruh serta merasakan kebermanfaatannya, jadi siswa diwajibkan supaya menguasai beberapa kemampuan. Belajar matematika memang tidak ada akhirnya, mulai dari sekolah dasar 
sampai dengan keperguruan tinggi pasti akan belajar matematika, bahkan sampai kapan pun kita akan harus belajar. Oleh karena itu matematika sering disebut yaitu ratunya ilmu. Matematika ialah ilmu mengenai kuantitas, struktur, ruang, dan perubahan. Matematika menjadi suatu ilmu yang mendasari kehidupan manusia. Sejak ditemukannya, ilmu matematika selalu berkembang sesuai dengan berkembangnya zaman secara dinamis. Perkembangan ilmu matematika tidak pernah berhenti karena matematika sangat dibutuhkan pada berbagai aspek kehidupan manusia untuk mendapatkan kehidupan yang sempurna. Akan tetapi bagi siswa matematika itu tidak indah seperti namanya ratunya ilmu, menurut siswa belajar matematika itu sukar apalagi tingkat sekolah menengah pertama. Pendapat mereka belajar matematika itu membosankan, jadi mengantuk apabila gurunya sudah tua dan seram menakutkan. Oleh karena itu pada penelitian ini peneliti mau melihat penyebab/faktor yang mempengaruhi minat belajar siswa didunia pendidikan dan pada pembelajaran khususnya mata pelajaran matematika (Pasaribu, 2020).

Minat belajar merupakan suatu ketertarikan terhadap suatu pelajaran yang kemudian mendorong individu untuk mempelajari dan menekuni pelajaran tersebut. Pendapat (Pohan, 2020) Minat belajar timbul disebabkan kemauan pada diri sendiri pribadi seseorang maupun faktor yang berpengaruh dari luar. Minat belajar juga tidak hanya tergantung pada keinginan siswa tetapi juga di pengaruhi di segala kegiatan belajar siswa yakni guru yang mengajar, sarana dan prasarana, kemampuan orang tua, bahan pelajaran, sekitaran sekolah, faktor fisik dan rohani serta metode dan strategi pembelajaran. Begitu banyaknya persoalan dipembelajaran tentunya membuat minat siswa untuk belajar menjadi rendah. Padahal (Safitri, 2016) Hal yang tidak kalah penting yang wajib punya peserta didik yaitu kemandirian pada belajar, terutama kemandirian pada belajar matematika. Sesuai pada pendapat tersebut. Dari beberapa indikator tersebut bisa disimpulkan bahwa indikator minat belajar ialah 1) adanya perasaan bahagia terhadap pembelajaran, 2) adanya pemusatan perhatian dan pikiran pada pembelajaran, 3) adanya niat untuk belajar, 4) adanya keinginan dari dalam diri untuk aktif pada pembelajaran, 5) adanya upaya yang dilaksanakan untuk merealisasikan kemauan untuk belajar. Oleh sebab itu akan dilaksanakan analisis untuk melihat bagaimana minat belajar siswa disaat pembelajaran matematika secara klasikal dan berdasarkan gender. Diharapkan dengan menganalisis minat belajar siswa bisa diketahui sejauh mana tingkat minat belajar yang dipunyai siswa baik secara klasikal maupun berdasarkan gender khususnya untuk pembelajaran matematika sehingga bisa menjadi evaluasi dan diperoleh solusi untuk lebih meningkatkan lagi minat belajar siswa (Friantini \& Winata, 2019).

Komunikasi merupakan suatu sarana untuk menyampaikan suatu pesan yang hendak disampaikan untuk tujuan tertentu. Dalam pembelajaran perlu adanya kemampuan komunikasi yang baik guna untuk menjelaskan atau menyampaikan suatu kejadian yang ada di sekolah atau di lingkungan sekitar. Permendiknas nomor 22 tahun 2006 mengungkapkan salah satu tujuan pembelajaran matematika di jenjang pendidikan dasar dan menengah adalah mampu mengkomunikasikan gagasan dengan simbol, tabel, diagram atau media lain untuk memperjelas keadaan atau masalah. Menurut (Fajriah \& Nor, 2018) Kemampuan komunikasi merupakan suatu kemampuan harus ada peserta didik untuk belajar matematika. Komunikasi sangatlah berguna karena mampu menolong peserta didik untuk cara pengolahan pikiran, 
menghubungkan pendapatnya dengan pendapat yang lainnya, jadi mampu memenuhi hal- hal rendah untuk semua jaringan pendapat peserta didik. Pendapat (Autograph et al., 2017) Misi guru adalah suatu kelompok yang memiliki peran sangat penting. Suatu upaya untuk membangunkan misi pendidikan di sekolah yaitu dengan cara memperbaiki proses belajar mengajar atau pembelajaran. Sejalan dengan menurut (Hidayat, 2018) Suatu yang bisa dilaksanakan membangun proses pembelajaran dan mengoptimalkan kemampuan komunikasi matematis siswa yaitu dengan melakukan model pembelajaran yang berbeda dan yang lebih penting bisa mengoptimalkan kemampuan komunikasi matematis siswa. Menurut (Pasaribu, 2016) menyatakan bahwa komunikasi adalah salah satu dari standart proses pembelajaran. Dimana dalam komunikasi hal ini tidak sekedar komunikasi secara lisan ataupun verbal tetapi juga komunikasi secara tertulis. Komunikasi merupakan salah satu standar proses pembelajaran dan komunikasi tidak hanya sekedar lisan tetapi juga secara tulisan. Sejalan dengan pendapat (Suriyani, 2016) Guru terutama menekan peserta didik untuk menghapal simbol dan rumus matematika, begitu membuat bukan adanya pembangunan kemampuan siswa pada berkomunikasi matematika. Jadi pada akhirnya ketika peserta didik di minta supaya menerangkan sesuatu tentang matematika, peserta didik itu tidak bisa mengetahui karena mereka tidak sanggup berkomunikasi dengan baik pada matematika, peserta didik hanya mengetahui rumus dan itu pun karena menghapal.

Menurut (Ahmad, 2018) menjelaskan kemampuan komunikasi matematis adalah: (1) mampu mengatakan suatu kejadian ke dalam bentuk bahasa, simbol, ide matematika; (2) menjabarkan ide, keadaan, dan relasi matematika ke dalam bentuk bahasa biasa; (3) mendengarkan, berdiskusi, dan menulis mengenai matematika; (4) memahami suatu penjabaran matematika; (5) menyampaikan kembali suatu masalah matematika dalam bahasa sendiri. Rendahnya pembelajaran teorema pythagoras hal ini juga dapat disebabkan oleh kemampuan komunikasi dan kemandirian siswa dalam belajar. Dalam dunia nyata pembelajaran teorema pythagoras sangat dibutuhkan karena berhubungan dalam kehidupan sehari-hari. Berdasarkan (Muliana, 2020) agar mampu terwujudnya kemampuan komunikasi maka hendaknya pembelajaran matematika selalu ditujukan sehingga peserta didik dapat menguasai matematika dengan baik dan optimal.

Kemandirian siswa yakni kondisi kegiatan belajar yang mandiri tidak bergantung pada orang lain, mempunyai kemauan, inisiatif serta bertanggung jawab sendiri untuk menyelesaikan masalah belajarnya. Kemandirian siswa akan terwujud apabila siswa aktif mengontrol sendiri semua yang dilakukan, mengevaluasi dan selanjutnya merencanakan sesuatu yang lebih pada pembelajaran yang dilewati dan siswa juga mau aktif pada proses pembelajaran. (Dewi et al., 2020a) Pendapat Bungsu, Vilardi, Akbar, \& Bernard (2018), mandiri adalah kata dasar dari kemandirian yang artinya berdiri sendiri, yaitu situasi dimana bisa seseorang untuk mengatur dan mengatur diri sesuai di tingkat perkembangannya. Menurut (Arifin \& Herman, 2018) Suatu alasan yang mendorong siswa wajib belajar mandiri yaitu zaman ini banyaknya sumber belajar dapat diambil peserta didik dari bermacam media. Belajar bukan terputus hanya disekolah, tapi boleh kapan saja dan dimana saja. Sekarang guru tidak hanya salah satu sumber belajar terhadap peserta didik. Peserta didiklah wajib aktif belajar mandiri supaya meningkatkan ilmu pribadinya. (Robiana \& 
Handoko, 2020) Menyadari bahwa pentingnya komunikasi matematis dan kemandirian belajar siswa, guru dapat membuat media pembelajaran yang bisa memberikan peluang dan mendorong siswa untuk melatih kemampuan komunikasi matematis dan kemandirian belajar siswa.

Berdasarkan hasil wawancara dengan salah satu guru pelajaran matematika di SMP Negeri 1 Pangkatan, bahwa minat belajar siswa sangat rendah terhadap kemampuan komunikasi dan siswa mengalami kesulitan untuk belajar secara mandiri. Hal ini disebabkan masih banyaknya siswa yang bergantung dengan sumber yang diberikan oleh guru. Begitupun ketika guru memberikan tugas, siswa saling bergantung pada teman yang lainnya. Serupa dengan penelitian yang dilakukan (Dewi et al., 2020a) yang melaporkan rendahnya kemandirian belajar siswa dalam pembelajaran matematika menyebabkan hasil belajar menjadi rendah. Beberapa penyebabnya diantaranya kurangnya motivasi belajar, jenuh dan kurangnya keaktifan siswa. Oleh sebab itu, penelitian ini bertujuan menganalisis untuk mengetahui pengaruh minat belajar terhadap kemampuan komunikasi dan kemandirian siswa.

\section{METODE}

Metode penelitian ini adalah penelitian korelasional. Dalam penelitian ini terdapat 3 variabel, yakni dua variabel independen (bebas) yaitu $\mathrm{X}_{1}$ (kemampuan komunikasi) dan $\mathrm{X}_{2}$ (kemandirian siswa) serta satu variabel dependen (terikat) yaitu Y (minat belajar siswa). Hubungan antara variabel tersebut dapat dilihat pada bagan berikut ini:

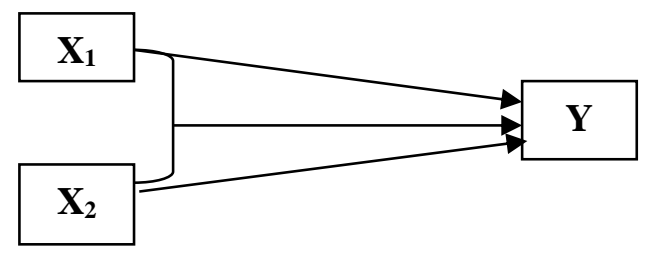

Bagan 1. Hubungan antar variabel

$\mathrm{X}_{1}=$ Kemampuan komunikasi

$\mathrm{X}_{2}=$ Kemandirian siswa

$\mathrm{Y}=$ Minat Belajar Siswa

Untuk mencari hubungan $\mathrm{X}_{1}$ dengan $\mathrm{Y}$, dan $\mathrm{X}_{2}$ dengan $\mathrm{Y}$ menggunakan teknik analisi data uji regresi berganda. Dan untuk mencari hubungan $\mathrm{X}_{1}$ dengan $\mathrm{X}_{2}$ secara simultan (bersamaan) terhadap $\mathrm{Y}$ menggunakan teknik analisis data uji korelasi berganda. Penelitian dilaksanakan pada bulan Februari-Maret Tahun 2021 pada semester genap Tahun Pembelajaran 2020/ 2021. Populasi pada penelitian ini yaitu dilakukan di SMP Negeri 1 Pangkatan. Dan sampel pada penelitian ini adalah siswa kelas VIII SMP Negeri 1 Pangkatan sebanyak 30 siswa, dengan teknik pengambilan sampel menggunakan teknik simple random sampling. Teknik pengumpulan data menggunakan tes essay dan angket. Dimana tes essay yang terdiri dari 10 soal digunakan untuk mengukur kemampuan komunikasi siswa. Dan angket digunakan untuk mengukur kemampuan kemandirian siswa. Teknik analisis data penelitian ini adalah statistik deskriptif menggunakan 
Hubungan Minat Belajar Siswa Terhadap Kemampuan Komunikasi dan Kemandirian Siswa pada Materi Teorema Pythagoras, Siti Liwinda Rumapea, Laili Habibah Pasaribu

uji regresi berganda. Penelitian ini bertujuan untuk mengetahui seberapa besar pengaruh minat belajar siswa terhadap kemampuan komunikasi dan kemandirian siswa pada materi teorema pythagoras.

\section{HASIL DAN DISKUSI}

Penelitian ini diawali dengan pemberian tes untuk mengukur kemampuan komunikasi dan kemandirian siswa melalui minat belajar pada teorema pythagoras yang terdiri dari 10 butir soal. Selanjutnya, siswa diberi angket untuk mengetahui tingkat kemandirian belajar siswa. Penelitian ini dilakukuan untuk membuktikan apakah ada peningkatan antara variabel bebas $\mathrm{X}_{1}$ (kemampuan komunikasi) dan $\mathrm{X}_{2}$ (kemandirian siswa) dengan variabel terikat $\mathrm{Y}$ (minat belajar siswa) yang dilakukan dengan menggunakan teknik analisis data uji regresi berganda. Dari hasil perhitungan diperoleh nilai sebagai berikut: nilai $\mathrm{R}=0.243$ maka menurut kriteria yang diperoleh membuktikan bahwa hubungan ketiga variabel tersebut sangat erat. Sedangkan koefsien determinasi sebesar 0.059. Hasil perhitungan dapat dilihat pada tabel berikut.

Tabel 1 Pengujian Hipotesis dengan Uji $t$

Coefficients $^{\mathrm{a}}$

\begin{tabular}{|c|c|c|c|c|c|c|}
\hline \multirow{2}{*}{\multicolumn{2}{|c|}{ Model }} & \multicolumn{2}{|c|}{$\begin{array}{c}\text { Unstandardiz } \\
\text { ed } \\
\text { Coefficients }\end{array}$} & \multirow{2}{*}{$\begin{array}{c}\text { Standardized } \\
\text { Coefficients } \\
\text { Beta }\end{array}$} & \multirow[b]{2}{*}{$\mathrm{t}$} & \multirow[b]{2}{*}{ Sig. } \\
\hline & & B & Std. Error & & & \\
\hline 1 & $\begin{array}{l}\text { (Constant) } \\
\text { Berpikir Kreatif } \\
\text { Kemandirian Siswa }\end{array}$ & $\begin{array}{c}73,173 \\
-, 080 \\
, 099\end{array}$ & $\begin{array}{c}9,194 \\
, 090 \\
, 161\end{array}$ & $\begin{array}{c}-, 288 \\
, 199\end{array}$ & $\begin{array}{l}7,958 \\
-, 888 \\
, 612\end{array}$ & $\begin{array}{l}, 000 \\
, 382 \\
, 545\end{array}$ \\
\hline
\end{tabular}

a. Dependent Variable: PMR

Dari tabel diatas diketahui nilai signifikan untuk pengaruh kemampuan komunikasi $\left(\mathrm{X}_{1}\right)$ terhadap minat belajar siswa (Y) adalah sebesar $0.210<0.05$, dan nilai $\mathrm{t}_{\text {hitung }}-1.279>\mathrm{t}_{\text {tabel }} 2.04841$. Sehingga dapat disimpulkan bahwa terdapat pengaruh kemampuan komunikasi $\left(\mathrm{X}_{1}\right)$ terhadap minat belajar siswa $(\mathrm{Y})$. Dan juga diketahui nilai signifikan untuk pengaruh kemandirian siswa $\left(\mathrm{X}_{2}\right)$ terhadap minat belajar siswa (Y) adalah sebesar $0.170>0.05$, dan nilai $\mathrm{t}$ hitung $1.402<\mathrm{t}$ tabel 2.04841 . Sehingga dapat disimpulkan bahwa tidak terdapat pengaruh kemandirian siswa $\left(\mathrm{X}_{2}\right)$ terhadap minat belajar siswa $(\mathrm{Y})$.

Tabel 2. Pengujian Hipotesis Dengan Uji F

ANOVA ${ }^{\mathrm{a}}$

\begin{tabular}{|ll|c|c|c|c|c|}
\hline & Model & Sum of Squares & df & Mean Square & F & Sig. \\
\hline 1 & Regression & 144,123 & 2 & 72,062 & 1,005 &, $377^{\mathrm{b}}$ \\
& Residual & 2294,448 & 32 & 71,701 & & \\
& Total & 2438,571 & 34 & & & \\
\hline
\end{tabular}

a. Dependent Variable: Minat Belajar

b. Predictors: (Constant), Kemandirian Siswa, Kemampuan Komunikasi

Berdasarkan tabel diatas diketahui nilai signifikan untuk pengaruh $\mathrm{X}_{1}$ dan $\mathrm{X}_{2}$ secara simultan terhadap $\mathrm{Y}$ adalah sebesar $0.377<0.05$ dan nilai $\mathrm{F}_{\text {hitung }} 1.005>\mathrm{F}_{\text {tabel }}$ 3.34. Sehingga dapat disimpulkan bahwa terdapat 
pengaruh minat belajar siswa terhadap kemampuan komunikasi dan kemandirian siswa pada materi teorema pythagoras. kemampuan komunikasi dan kemandirian siswa secara simultan terhadap minat belajar adalah sebesar $0.377>0.05$ dan nilai F hitung $1.005<3.34$, Maka dapat disimpulkan bahwa tidak dapat pengaruh minat belajar siswa terhadap kemampuan komunikasi dan kemandirian siswa pada materi teorema pythagoras.

Tabel 3. Koefisien Determinasi

\section{Model Summary}

\begin{tabular}{|c|c|c|c|c|}
\hline Model & $\mathrm{R}$ & $\mathrm{R}$ Square & Adjusted R Square & $\begin{array}{c}\text { Std. Error of the } \\
\text { Estimate }\end{array}$ \\
\hline 1 &, $243^{\mathrm{a}}$ &, 059 &, 000 & 8,46767 \\
\hline
\end{tabular}

a. Predictors: (Constant), Kemandirian Siswa, Kemampuan Komunikasi

Berdasarkan tabel diatas diketahui nilai R Square sebesar 0.059, hal ini mengandung arti bahwa pengaruh variabel $\mathrm{X}_{1}$ (kemampuan komunikasi) dan variabel $\mathrm{X}_{2}$ (kemandirian siswa) secara simultan (bersamaan) terhadap variabel Y (minat belajar siswa) adalah sebesar 59\%.

\section{KESIMPULAN}

Dari data angket dan tes yang diberikan kepada siswa kelas VIII-4 SMP Negeri 1 Pangkatan diperoleh nilai signifikan untuk mempengaruhi kemampuan komunikasi terhadap minat belajar adalah sebesar 0,210 > 0,05, dan nilai $t$ hitung $-1,279<\mathrm{t}$ tabel 2,04841 sehingga dapat disimpulkan tidak dapat mempengaruhi minat belajar terhadap kemampuan komunikasi, dan nilai signifikan untuk mempengaruhi kemandirian siswa terhadap minat belajar adalah sebesar $0,170>0,05$ dan nilai $\mathrm{t}$ hitung $1,402<\mathrm{t}$ tabel 2,04841 sehingga dapat disimpulkan tidak dapat mempengaruhi minat belajar terhadap kemandirian siswa. Nilai signifikan untuk mempengaruhi kemampaun komunikasi dan kemandirian siswa secara simultan terhadap minat belajar adalah sebesar 0,377 >0,05 dan nilai F hitung 1,005 <3,34. Maka dapat disimpulkan bahwa tidak dapat pengaruh minat belajar siswa terhadap kemampuan komunikasi dan kemandirian siswa pada materi teorema pythagoras. Bahwa mempengaruhi kemampuan komunikasi dan kemandirian siswa secara simultan terhadap minat belajar pada teorema pythagoras adalah sebesar 5,9\%. Berdasarkan dari rumusan masalah, hasil penelitian, dan pembahasan yang sudah dipaparkan sebelumnya, diperoleh kesimpulan sebagai berikut: terdapat pengaruh variabel bebas $\mathrm{X}_{1}$ (Kemampuan Komunikasi) dan $\mathrm{X}_{2}$ (Kemandirian Siswa) dengan variabel terikat Y (Minat Belajar Siswa) yang bisa dilihat hasilnya: Fhitung $<$ Ftabel. $=1.005<3.34$

\section{UCAPAN TERIMA KASIH}

Puji dan Syukur penulis panjatkan kehadirat Tuhan Yang Maha Esa telah memberikan petunjukNya sehingga penulis dapat menyelesaikannya. Terimakasih penulis ucapkan kepada Bapak/Ibu Kepala Sekolah SMPN 1 Pangkatan yang telah bersedia memberikan izin, dan membantu penulis untuk menyelesaikan penelitian ini. Terimakasih kepada Bapak/Ibu Dosen yang telah membimbing selama ini 
Hubungan Minat Belajar Siswa Terhadap Kemampuan Komunikasi dan Kemandirian Siswa pada Materi Teorema Pythagoras,

sehingga dapat menyelesaikan publikasi ini. Terimakasih kepada Orang Tua, Teman - Teman dan Saudara/i yang sudah memberikan dukungan dan doanya.

\section{REFERENSI}

Arifin, F., \& Herman, T. (2018). Pengaruh Pembelajaran E-Learning Model Web Centric Course Terhadap Pemahaman Konsep Dan Kemandirian Belajar Matematika Siswa. Jurnal Pendidikan Matematika, 12(2), 1-12.

Dewi, N., Asifa, S. N., \& Zanthy, L. S. (2020a). Pengaruh Kemandirian Belajar Terhadap Hasil Belajar Matematika. PYTHAGORAS: Jurnal Program Studi Pendidikan Matematikka, 9(1), 48-54.

Dewi, N., Asifa, S. N., \& Zanthy, L. S. (2020b). Pengaruh Kemandirian Belajar Terhadap Hasil Belajar Matematika. PYTHAGORAS: Jurnal Program Studi Pendidikan Matematikka, 9(1), 48-54.

Ernawati, E. (2020). Pengaruh Pembelajaran Problem Based Learning Terhadap Kemampuan Komunikasi dan Self Efficacy Matematis Siswa. Jurnal Pembelajaran Dan Matematika Sigma (Jpms), 6(2), 62 71. https://doi.org/10.36987/jpms.v6i2.1851

Fajriah, N., \& Nor, J. (2018). Kemampuan Komunikasi Matematis Siswa Pada Materi Teorema Pythagoras Di Kelas Viii Smp Negeri 15 Banjarmasin Tahun Pelajaran 2016/2017. EDU-MAT: Jurnal Pendidikan Matematika, 5(2), 202-208. https://doi.org/10.20527/edumat.v5i2.4648

Friantini, R. N., \& Winata, R. (2019). Analisis Minat Belajar pada Pembelajaran Matematika. JPMI (Jurnal Pendidikan Matematika Indonesia), 4(1), 6. https://doi.org/10.26737/jpmi.v4i1.870

Hidayat, A. (2018). Pengaruh Model Pembelajaran Berbasis Masalah Dengan Pendekatan Pemecahan Masalah Terhadap Kemampuan Komunikasi Matematis Siswa Smp Negeri 1 Rumbio Jaya. Jurnal Cendekia : Jurnal Pendidikan Matematika, 2(1), 23-40. https://doi.org/10.31004/cendekia.v2i1.30

Mayasari, \& Rosyana, T. (2019). Pemecahan Masalah Matematis Siswa Smp. Jurnal Cendikia: Pendidikan Matematika, 3(1), 82-89.

Muliana, M., \& Nuraina, N. (2020). Peningkatan Kemampuan Komunikasi Matematis Siswa Kelas VIII SMP dengan Model Pembelajaran Kooperatif Tipe Teams Games Tournamen (TGT) dan Alat Peraga. Jurnal Pembelajaran Dan Matematika Sigma (Jpms), 6(2), 41-46. https://doi.org/10.36987/jpms.v6i2.1679

Negeri, S. M. P., Utara, R., \& Hasibuan, L. R. (2015). Pengaruh Pembelajaran Matematika Dengan Menggunakan Model Reciprocal Teaching Terhadap Kemampuan Komunikasi Matematika Siswa Di Kelas Vii. 1(2), 27-36.

Pasaribu, L. H. (2016a). Peningkatan Kemampuan Komunikasi Matematika Siswa Melalui Pembelajaran ( Pmr ) Di Kelas Vii Smp Negeri 1 Na Ix-X Aek Kota Batu. 2(2), 7-12. Jurnal Pembelajaran Dan Matematika Sigma (JPMS).

Pasaribu, L. H. (2016b). PEningkatan Kemampuan Komunikasi Siswa Melalui Pendekatan Problem Based Learning ( PBL) Terhadap Siswa MTs N KELAS VII Pendekatan Problem Based Learning. 2(1).

Pasaribu, L. H. (2020). Pengaruh Motivasi,Minat Belajar Dan Lingkungan Terhadap Prestasi Belajar 
Matematika Siswa. Mathematic Education Journal)MathEdu, 3(2), 106-108. http://journal.ipts.ac.id/index.php/

Permatasari, D. P., Gunowibowo, P., \& Coesamin, M. (2017). PENGARUH MODEL RECIPROCAL TEACHING terhadap peningkatan kemampuan komunikasi matematis siswa. Jurnal Pendidikan Matematika Universitas Lampung, 5(1), 1-8.

Pohan, Y. (2020). Pengaruh Penggunaan Internet Terhadap Minat dan Hasil Belajar Matematis Siswa Kelas VIII SMP Negeri 1 Kualuh Selatan. Jurnal Pembelajaran Dan Matematika Sigma (Jpms), 6(2), 93100. https://doi.org/10.36987/jpms.v6i2.1850

Robiana, A., \& Handoko, H. (2020). Pengaruh Penerapan Media UnoMath untuk Meningkatkan Kemampuan Komunikasi Matematis dan Kemandirian Belajar Siswa. Mosharafa: Jurnal Pendidikan Matematika, 9(3), 521-532.

Safitri, I. (2016). Penerapan Pendekatan Pembelajaran Realistic Mathematics Education ( RME ) Dalam Upaya Meningkatkan Kemandirian Belajar Matematika Siswa Penerapan Pendekatan Pembelajaran Realistic Mathematics Education ( RME ) Dalam. Jurnal Pembelajaran Dan Matematika Sigma (JPMS), 2(1).

Suriyani. (2016). Pengaruh Penerapan Open-Ended Terhadap Kemampuan. 2(2), 40-45. Jurnal Pembelajaran Dan Matematika Sigma (JPMS). 